\title{
SEED QUALITY AND GENETIC DIVERSITY OF A CULTIVATED POPULATION OF Mimosa caesalpiniifolia BENTH $^{1}$
}

\author{
FERNANDO DOS SANTOS ARAÚJO ${ }^{2}$, FRANCIVAL CARDOSO FELIX ${ }^{2}$, CIBELE DOS SANTOS FERRARI ${ }^{2}$, FÁBIO \\ DE ALMEIDA VIEIRA ${ }^{2}$, MAURO VASCONCELOS PACHECO ${ }^{2 *}$
}

\begin{abstract}
Mimosa caesalpiniifolia Benth. (Fabaceae) is a native tree of the dry tropical forests of northeastern Brazil and can be exploited for logging and reforestation purposes. This study evaluated the physiological quality of seeds and the genetic diversity of a cultivated population of $M$. caesalpiniifolia, against the background of potential commercial seed production. Nine trees were used in the study. The quality of their seeds was evaluated by germination and vigour tests, and their genetic diversity was accessed using Inter Simple Sequence Repeat (ISSR). The studied tree group presents a moderate genetic diversity and produces seeds with high physiological quality, but with subtle vigour differences, which can be detected by electrical conductivity and potassium leaching tests. Our results suggest that these trees are potentially suitable for commercial seed production.
\end{abstract}

Keywords: Forest seeds. Molecular marker. Physiological quality. Semiarid. Sabiá.

\section{QUALIDADE DE SEMENTES E DIVERSIDADE GENÉTICA DE UMA POPULAÇÃO CULTIVADA DE Mimosa caesalpiniifolia BENTH}

RESUMO - Mimosa caesalpiniifolia Benth. (Fabaceae) é uma árvore nativa das florestas tropicais secas do Nordeste do Brasil e pode ser explorada para fins madeireiros e reflorestamento. Este estudo avaliou a qualidade fisiológica de sementes e a diversidade genética de uma população cultivada de M. caesalpiniifolia, tendo como base de sustentação o potencial para produção comercial de sementes. Nove árvores matrizes foram usadas no estudo. A qualidade de suas sementes foi avaliada por testes de germinação e vigor, e sua diversidade genética foi acessada usando o Inter Simple Sequence Repeat (ISSR). O grupo de árvores estudado apresenta uma diversidade genética moderada e produz sementes com alta qualidade fisiológica, mas com sutis diferenças de vigor, que podem ser detectadas por testes de condutividade elétrica e lixiviação de potássio. Esses resultados sugerem que essas árvores são potencialmente adequadas para a produção comercial de sementes.

Palavras-chave: Sementes florestais. Marcador molecular. Qualidade fisiológica. Semiárido. Sabiá.

${ }^{2}$ Academic Unit Specialized in Agricultural Sciences, Universidade Federal do Rio Grande do Norte, Macaíba, RN, Brazil; nandosantos005@hotmail.com - ORCID: 0000-0002-0605-1613, francival007@gmail.com - ORCID: 0000-0002-6518-5697, cibeferrari@hotmail.com _ ORCID: 0000-0003-2940-0190, vieirafa@gmail.com _ ORCID: 0000-0003-3347-255X, pacheco.sementes@gmail.com - ORCID: 0000-0002-0447-9800.
} 


\section{INTRODUCTION}

Mimosa caesalpiniifolia Benth. (Fabaceae) is a woody tree native to dry tropical forests in northeastern Brazil. It is of high economic importance for the forest sector of this region because its wood is resistant to xylophagous termites (ARAUJO; PAES, 2018) and has is used in the production of charcoal; the species is also used in forest restoration (COSTA et al., 2014). Because of the importance of $M$. caesalpiniifolia to the forest sector in Brazilian semi-arid regions, the demand for its seeds is expected to increase in the near future. This warrants implementation related to the production of seeds, both for the purpose of economic exploitation of the products and for forest restoration.

High-quality seeds and technical planning are required for all production stages, starting with the selection of trees from which the seeds will be collected (NOGUEIRA; MEDEIROS, 2007). Therefore, seed quality control in the laboratory is necessary prior to the selection of suitable trees (LIMA et al., 2014).

To evaluate the quality of forest seeds of matrix trees, germination and vigour tests are used (SILVA et al., 2014a; CORREIA et al., 2019; NUNES et al., 2019). The latter can detect differences in the physiological quality of the seeds that are not detected by the germination test (KRZYZANOWSKI; FRANÇA NETO, 2001).

Although a high physiological seed quality is essential, genetic characterisation of matrix trees is also important to ensure that the resulting population has compatible genetic diversity levels. For environmental reforestation, for example, Sebbenn (2002) recommends that matrix trees for seed supply present a low degree of relatedness in order to avoid inbreeding in future generations and to preserve the evolutionary potential of the population established.

In Brazil, the genetic characterisation of seed source populations of native trees is routinely performed using genetic markers, such as morphological (COSTA et al., 2016; ROVERI NETO; PAULA, 2017; CORREIA et al., 2019; FELIX et al., 2020) and/or DNA (or molecular) analysis. Commonly used markers are Random Amplified Polymorphic DNA (RAPD) (RABBANI; SILVA-MANN; FERREIRA, 2012; BELARMINO et al., 2017; ALMEIDA NETO et al., 2019) and Inter Simple Sequence Repeats (ISSR) (DUARTE; NOGUEIRA; VIEIRA, 2018; SILVA JÚNIOR et al., 2017). Of these, ISSR markers are more accessible and do not require prior knowledge of the genome of species to design primers, which is still small for native Brazilian tree species.
Little is known about the seed quality of $M$. caesalpiniifolia and the genetic composition of the seed source of existing populations. Therefore, the objective of this study is to evaluate the genetic diversity and seed physiological quality of trees from seed source populations.

\section{MATERIAL AND METHODS}

\section{Sampling}

Sampling was carried on a cultivated population of 355 trees $(67 \%$ without prickles and $33 \%$ with prickles) located in the Forest Experimentation Area (5 53'52.0" S and 35 21'31.0" $\mathrm{W})$ of the Unidade Acadêmica Especializada em Ciências Agrárias (UAECIA)/Universidade Federal do Rio Grande do Norte (UFRN) of Macaíba City, Rio Grande do Norte State, Brazil. According to the Köppen classification, the climate of this region varies between types $\mathrm{A}^{\prime}$ and $\mathrm{BSh}$ ', with dry and rainy seasons.

Of the cultivated population, 20 reproductive trees were randomly sampled, but only nine of them provided sufficient seeds for the physiological tests. Among those nine trees, three were phenotypes with prickles (1, 2 and 5) and six were without prickles (3, 4, 6, 7, 8 and 9). The seeds were collected in AugustDecember 2013 manually and stored for evaluation of physiological quality.

Tissue samples (young leaves) were collected from all nine trees, deposited in sterile plastic tubes in an icebox and sent to the Laboratory of Genetics and Forest Improvement of the UFRN. At the laboratory, the samples were transferred to tubes containing buffer solution (CTAB 2.0\%) and stored at $-20^{\circ} \mathrm{C}$ prior to DNA extraction.

\section{Genetic diversity analyses}

The genomic DNA was extracted according to the protocol proposed by Doyle and Doyle (1990), and the extracted DNA was quantified using a microplate spectrophotometer (Epoch ${ }^{\mathrm{TM}}$ ) according to the manufacturer's instructions.

Genetic diversity was estimated using ISSR markers amplified by the Polymerase Chain Reaction (PCR-ISSR) technique. Seven primers, which were recommended by Araújo et al. (2016) for genetic studies in $M$. caesalpiniifolia, were used: 807 (AG) 8T, 824 (TC) 8G, 827 (AC) 8G, 840 (GA) 8YT, 851 (GT) 8 YG, 873 (GACA) 4 and 881 (GGGGT) 3 (set \# 9 - Nucleic Acid-Protein Service Unit, University of British Columbia, USA) (Table 1). 
F. S. ARAÚJO et al.

Table 1. Nucleotide sequences of the seven primers used in ISSR.

\begin{tabular}{ll}
\hline Code & Nucleotide sequence (5’-3') \\
\hline $807($ AG) $8 \mathrm{~T}$ & AGA GAG AGA G AG AGA GT \\
$824(\mathrm{TC})$ 8G & TCT CTC TCT CTC TCT CG \\
$827(\mathrm{AC})$ 8G & ACA CAC ACA CAC ACA CG \\
$840(\mathrm{GA}) 8 \mathrm{YT}$ & GAG AGA GAG AGA GAG AYT \\
$851(\mathrm{GT}) 8 \mathrm{YG}$ & GTG TGT GTG TGT GTG TYG \\
$873(\mathrm{GACA}) 4$ & GAC AGA CAG ACA GAC A \\
$881(\mathrm{GGGGT}) 3$ & GGG TGG GGT GGG GTG \\
\hline $\mathrm{Y}=\mathrm{C}$ or $\mathrm{T}$ &
\end{tabular}

The PCR amplifications were performed in $12.0 \mu \mathrm{L}$ reaction mix containing $2.0 \mu \mathrm{L}$ of template DNA ( $\left.20 \mathrm{ng} \mu \mathrm{L}^{-1}\right)$ added to $10.0 \mu \mathrm{L}$ reaction mixture [0.33 mM of primer, $1.2 \mu \mathrm{L}$ of PCR buffer (1X Buffer IC Phoneutria ${ }^{\circledR}$ ), $0.25 \mathrm{mg} \mathrm{mL}^{-1}$ of BSA, 2.0 $\mathrm{mM}$ of $\mathrm{MgCl}_{2}, 0.25 \mathrm{mM}$ of dNTP, $0.5 \mathrm{U}$ of Taq DNA polymerase and ultrapure water]. The DNA amplification was performed under the following conditions: initial denaturation at $94^{\circ} \mathrm{C}$ for 2 minutes; 37 cycles of 15 seconds at $94^{\circ} \mathrm{C}$ for denaturation, 30 seconds at $47^{\circ} \mathrm{C}$ for primer annealing with template DNA and 1 minute at $72^{\circ} \mathrm{C}$ for extension; the final extension cycle lasted for 7 minutes at $72^{\circ} \mathrm{C}$, followed by cooling to $4.0^{\circ} \mathrm{C}$.

The PCR products were stained with Bromophenol Blue associated to GelRed ${ }^{\mathrm{TM}}$ dye and separated by horizontal gel electrophoresis (agarose $1.5 \% \mathrm{~m} \mathrm{v}^{-1}$ ) immersed in $1 \mathrm{X}$ TAE buffer (TrisAcetate-EDTA) at a constant voltage $(100 \mathrm{~V})$ for about 3 hours. A negative control containing only PCR mix, with a standard molecular weight of 1,000 base pairs (bp) (K181 DNA Ladder Invitrogen ${ }^{\circledR}$ ), was used in each electrophoresis. Gels were photographed under ultraviolet light in a photo documentation system (E-Box VX2).

Reading of the information contained on the gels allowed the generation of a binary matrix, based on the presence (1) and absence (0) of bands in each locus. Subsequently, descriptive data analysis, involving the total number of bands (TNB), the number of polymorphic bands (NPB), the percentage of polymorphic bands (PPB) per primer and the mean polymorphic information content (PIC), was performed. The PIC values for each ISSR locus were calculated as proposed by Botstein et al. (1980). Based on the binary matrix with data, the following genetic diversity indices were estimated: percentage of polymorphism $(P)$, Shannon index $(I)$ Nei genetic diversity $(\mathrm{Ne})$ and genetic distance of Nei, using the statistical software POPGENE (version 1.3). A genetic divergent based on the genetic distance of
Nei was generated to obtain a dendrogram through hierarchical clustering, using the Unweighted Pair Group Method with Arithmetic mean (UPGMA) and the NTSYS software.

\section{Physiological quality analysis of seeds}

The seeds of the nine trees were sent to the Laboratory of Forest Seeds of the UFRN and subjected to the determination of moisture content and the evaluation of physiological quality. The moisture content (\%) was determined by oven-drying at $105 \pm 3^{\circ} \mathrm{C}$ for 24 hours according to Brasil (2009), using two subsamples of 50 seeds each.

The germination and vigour (emergence, emergence speed index, electrical conductivity and leaching of $\mathrm{K}^{+}$) tests were according to Avelino et al. (2018). For the germination test, the seeds were submitted to treatment to overcome dormancy (incision from the opposite region to the micropyle) and disinfestation with sodium hypochlorite solution $(2.5 \%$ of active chlorine) for 5 minutes. Subsequently, they were seeded on sterile paper previously moistened with distilled water equivalent to 2.5 times the weight of the dry paper. The paper was organised in the form of rolls, stored in transparent plastic bags and incubated in a germinator with B.O.D. (Biochemical Oxygen Demand) regulated at a temperature of $25^{\circ} \mathrm{C}$ with constant light (BRASIL, 2013). The experimental design used was completely randomised, using four replications of 25 seeds. On the day 7 , after the startup of the test, the germinated seeds were recorded (normal seedlings), and the results were expressed in percentages.

In the emergence test, the seeds were submitted to treatment to overcome dormancy (incision from the opposite region of the micropyle) and were seeded in rows $(60.0 \times 15.0 \mathrm{~cm})$ at a depth of $2.0 \mathrm{~cm}$ in a nursery bed under full sunlight. The experimental design used was in randomised blocks 
using four replications of 25 seeds each. On day 12 , emerged seedlings were recorded, and the results were expressed in percentages.

The emergence speed index was calculated based on the formula proposed by Maguire (1962), using the number of emerged seedlings per day.

In the electrical conductivity and leaching of potassium ion $\left(\mathrm{K}^{+}\right)$tests, we used 100 seed samples (divided into four replications of 25 seeds) with incision in the opposite region of the micropyle. Each subsample was weighed on an analytical balance and placed to soak in $50 \mathrm{~mL}$ of deionised water for 8 hours at $30^{\circ} \mathrm{C}$. After this period, the readings of electrical conductivity were performed using a bench conductivity meter $\left(\mathrm{Tecnal}^{\circledR}\right.$ model TEC-4MP) $\left(\mu \mathrm{S} \mathrm{cm} \mathrm{cm}^{-1}\right.$ of seed), and the concentration of $\mathrm{K}^{+}\left(\mathrm{mg} \mathrm{L}^{-1} \mathrm{~g}^{-1}\right.$ of seed) of the soaking solution was determined with a a flame photometer (Micronal ${ }^{\circledR}$ Model B462).

The treatments consisted of seeds of the nine trees (nine treatments). The data of variables that met the assumptions for parametric analysis (emergency, emergence speed index and leaching of potassium) were subjected to the F-test by Analysis of Variance (ANOVA), and variables that did not meet these assumptions were analysed using the non-parametric test of Kruskal-Wallis. The means were compared by the Scott-Knott test at 5\% probability. All analyses were performed using the statistical software ASSISTAT, version 7.6 beta.

\section{RESULTS AND DISCUSSION}

\section{Genetic diversity of different trees}

The genetic diversity measures for trees were as follows: $52.7 \%$ polymorphism, $0.220 \pm 0.02$ genetic diversity and $0.317 \pm 0.03$ Shannon index, indicating moderate rates of genetic diversity. As these species is probably self-incompatible (BLOCHTEIN et al., 2010) and trees come from a seminal source, a higher genetic diversity was expected.

However, the moderate genetic diversity observed in this study is compatible with that of other cultivated tree populations, as it agrees with the study conducted by Yiing et al. (2014), who revealed that cultivated populations of the tree species Neolamarckia cadamba (Roxb.) Bosser, with assisted reproduction, showed a lower genetic diversity $(I=0.149 ; P=35.1 \%)$ compared to the populations maintained in a wild state $(I=0.176 ; P=$ 48.4\%).

The genetic distance estimates for the nine trees ranged between 0.100 and 0.333 (Table 2), indicating that the trees are genetically divergent, but the genetic basis is narrow. This is probably a characteristic similar to that of other $M$. caesalpiniifolia seed orchards constituted by individuals without prickles, as they are generally rare.

Table 2. Genetic distance matrix of nine $M$. caesalpiniifolia trees.

\begin{tabular}{|c|c|c|c|c|c|c|c|c|c|}
\hline Matrix & 1 & 2 & 3 & 4 & 5 & 6 & 7 & 8 & 9 \\
\hline 1 & - & & & & & & & & \\
\hline 2 & 0.180 & - & & & & & & & \\
\hline 3 & 0.182 & 0.140 & - & & & & & & \\
\hline 4 & 0.120 & 0.220 & 0.160 & - & & & & & \\
\hline 5 & 0.197 & 0.200 & 0.243 & 0.100 & - & & & & \\
\hline 6 & 0.182 & 0.160 & 0.167 & 0.180 & 0.205 & - & & & \\
\hline 7 & 0.227 & 0.240 & 0.167 & 0.140 & 0.231 & 0.256 & - & & \\
\hline 8 & 0.218 & 0.256 & 0.149 & 0.205 & 0.298 & 0.254 & 0.179 & - & \\
\hline 9 & 0.151 & 0.140 & 0.269 & 0.200 & 0.205 & 0.231 & 0.333 & 0.298 & - \\
\hline
\end{tabular}

The dendrogram of the genetic distance for the tree set shows two clusters, taking as a cut-off point the first branch: cluster 1 formed by the trees 1 , 2, 4, 5, 6 and 9, and cluster 2 by the trees 3,7 and 8 (Figure 1). The trees 4 and $5(0.100)$ were the closest, while the trees 7 and $9(0.333)$ the most genetically distant ones (Table 2). These estimates allow seed collection in the most genetically distant trees. 


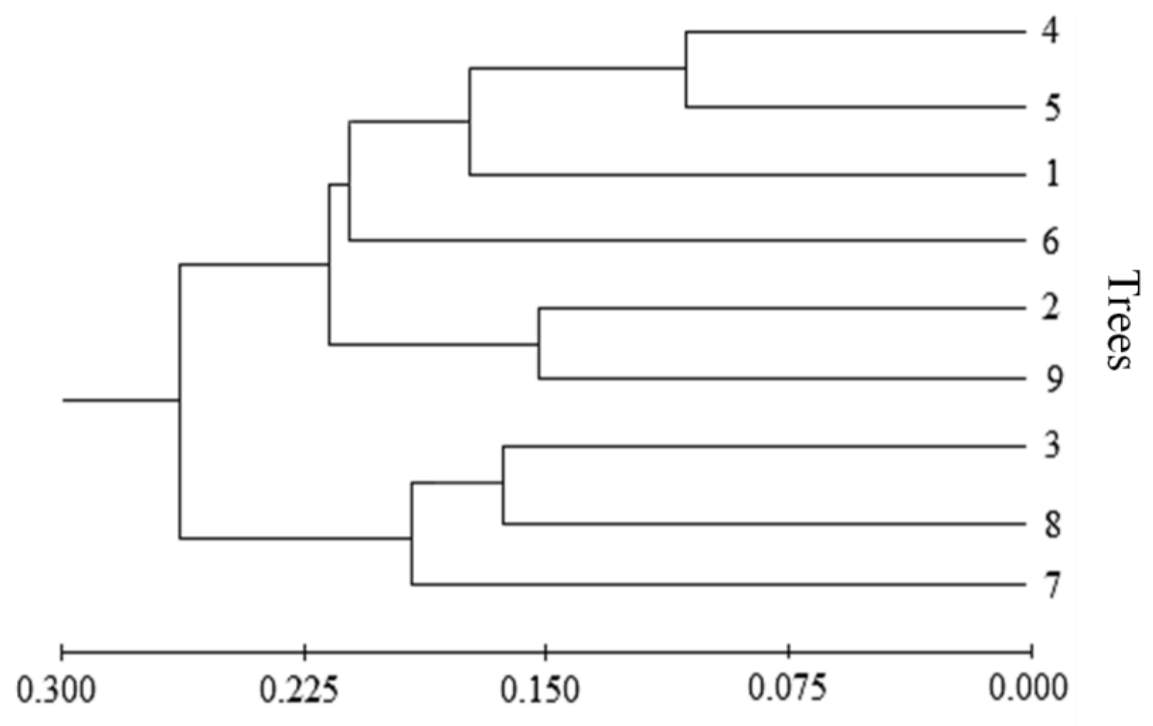

Nei genetic distance

Figure 1. Dendrogram UPGMA of Nei genetic distance for a set of nine trees of M. caesalpiniifolia.

Trees with desirable properties and genetically divergent in the population should be selected for seed collection, since they are essential for the formation of seed lots with greater genetic diversity (BELARMINO et al., 2017), as the more divergent the selected parents, the greater the variability of their progeny (MANFIO et al., 2012). This is of great value when the seeds are intended for forest recovery and germplasm conservation (SEBBENN, 2002).

\section{Physiological quality}

Regarding the moisture content, seeds of $M$. caesalpiniifolia showed levels of 9.1 to $11.0 \%$ (not statistically analysed data) (Table 3 ). This variation is within the allowed maximum limit of $2.0 \%$, which is necessary to standardise the assessments and to obtain consistent results in vigour tests (MARCOS FILHO, 2015). It may also verify a high percentage of seed germination and seedling emergence for all matrix trees, but do not was statistical significant differences these tests. However, for other variables (ESI, EC and KL), we found differences in the physiological quality among seeds of different trees. This leads us to infer that all trees produced highly viable seeds, but with differences in vigour.

Table 3. Average values of water content (WC), germination (G), emergence (E), emergence speed index (ESI), electrical conductivity (EC) and leaching of $\mathrm{K}^{+}(\mathrm{KL})$ of seeds from nine M. caesalpiniifolia trees.

\begin{tabular}{|c|c|c|c|c|c|c|}
\hline \multirow{2}{*}{ Tree } & $\mathrm{WC}(\%)$ & $\mathrm{G}(\%)$ & $\mathrm{E}(\%)$ & \multirow{2}{*}{ ESI } & \multirow{2}{*}{$\mathrm{EC}\left(\mu \mathrm{S} . \mathrm{cm}^{-1} \cdot \mathrm{g}^{-1}\right)$} & \multirow{2}{*}{$\mathrm{KL}\left(\mathrm{mg} \cdot \mathrm{L}^{-1} \cdot \mathrm{g}^{-1}\right)$} \\
\hline & \multicolumn{3}{|c|}{--------------------- \% ------------------ } & & & \\
\hline 1 & 11.0 & 93 & 66 & $2.75 \mathrm{c}$ & $254.11 \mathrm{~d}$ & $7.89 \mathrm{~d}$ \\
\hline 2 & 11.0 & 98 & 77 & $3.52 \mathrm{~b}$ & $140.95 \mathrm{~b}$ & $5.09 \mathrm{~b}$ \\
\hline 3 & 10.0 & 95 & 82 & $3.05 \mathrm{~b}$ & $148.84 \mathrm{~b}$ & $5.90 \mathrm{c}$ \\
\hline 4 & 11.0 & 93 & 71 & $3.21 \mathrm{~b}$ & $193.49 \mathrm{c}$ & $6.36 \mathrm{c}$ \\
\hline 5 & 11.0 & 97 & 72 & $3.25 \mathrm{~b}$ & $255.30 \mathrm{~d}$ & $7.19 \mathrm{~d}$ \\
\hline 6 & 9.1 & 98 & 68 & $4.03 \mathrm{a}$ & $111.30 \mathrm{a}$ & $4.71 \mathrm{~b}$ \\
\hline 7 & 9.5 & 93 & 77 & $3.55 \mathrm{~b}$ & $152.02 \mathrm{~b}$ & $5.90 \mathrm{c}$ \\
\hline 8 & 9.6 & 96 & 81 & $3.38 \mathrm{~b}$ & $160.07 \mathrm{~b}$ & $4.92 \mathrm{~b}$ \\
\hline 9 & 9.8 & 92 & 83 & $3.97 \mathrm{a}$ & $129.16 \mathrm{a}$ & $3.29 \mathrm{a}$ \\
\hline $\mathrm{CV}(\%)$ & - & 4.32 & 12.19 & 16.23 & 8.90 & 13.35 \\
\hline H-value & - & 8.9050 & - & - & 31.1532 & - \\
\hline p-value & - & - & 0.1159 & 0.0230 & - & 0.001 \\
\hline
\end{tabular}

$\mathrm{G}$ - not significant by the Kruskal-Wallis test $(\mathrm{H}<15.5073)$; E - not significant by the F-test $(\mathrm{p}>0.05)$; ESI - significant by the F-test $(\mathrm{p}<0.05)$; EC - significant by the Kruskal-Wallis test $(\mathrm{H}>15.5073)$; KL - significant by the F-test $(\mathrm{p}<0.05)$. Averages followed by the same letter in the column do not differ statistically by the Scott-Knott test at 5\% probability. 
Based on the emergence speed index, the seeds of trees 6 and 9 were classified as highly vigorous and those of tree 1 as less vigorous. In the evaluation of vigour based on the results of the electrical conductivity test, the seeds of trees 6 and 9 were also classified as highly vigorous, while the seeds of trees 1 and 5 were classified as less vigorous (Table 3 ). In the potassium-leaching test, only the seeds of tree 9 were classified as highly vigorous, while those of trees 1 and 5 were classified as less vigorous.

As the EC and KL tests are directly related to cell membrane integrity, it is believed that differences in solute leaching found in the seeds from the evaluated trees are a result of initial deterioration processes, such as damage to cell membranes, which have been identified as one of the first signs of the decline of the seed physiological quality (PANOBIANCO; VIEIRA; PERECIN, 2007; SHABAN, 2013; SILVA et al., 2014b). The EC and KL tests showed promising results regarding vigour difference detection among seeds from different Corymbia citriodora Hill \& Johnson trees (GONZALES; VALERI; PAULA, 2011). The variation between the seed physiological quality of different $M$. caesalpiniifolia trees in this study may be considered lower than of tree species such as Poincianella pyramidalis (Tul.) L.P. Queiroz (LIMA et al., 2014) and Sideroxylon obtusifolium (Roem. \& Schult.) T.D. Penn. (SILVA et al., 2014a) in wild populations. For the latter, the largest variation observed was attributed to the large environmental influence and the high genetic variability of individuals.

These results indicate that the tree set studied has moderate rates of genetic diversity and produces seeds with high percentages of germination and emergence, whose potential may be exploited for seed production.

\section{CONCLUSIONS}

The ISSR molecular markers and seed quality tests are important tools for the identification of $M$. caesalpiniifolia trees that show greater genetic divergence and produce better-quality seeds. The studied tree set has moderate rates of genetic diversity and produces seeds with high physiological quality, but with subtle vigour differences, which can be detected via electrical conductivity and potassium leaching tests. Our results suggest that these trees are potentially suitable for commercial seed production.

\section{ACKNOWLEDGEMENTS}

This study was financed in part by the Coordenação de Aperfeiçoamento de Pessoal de
Nível Superior - Brasil (CAPES) - Finance Code 001 and by the Fundação de Apoio à Pesquisa do Estado do Rio Grande do Norte (FAPERN). The access to genetic heritage of this research was registered in Sistema Nacional de Gestão do Patrimônio Genético e do Conhecimento Tradicional Associado (SisGen) and identified by the codes: A0C8FD7 and A5DB85E.

\section{REFERENCES}

ALMEIDA NETO, J. X. et al. Genetic diversity among and within brave bean (Capparis flexuosa L.) populations assessed using RAPD markers. Revista Caatinga, 32: 81-91, 2019.

ARAUJO, J. B. S.; PAES, J. B. Natural wood resistance of Mimosa caesalpiniifolia in field testing. Floresta e Ambiente, 25: e20150128, 2018.

ARAÚJO, F. S. et al. ISSR molecular markers for the study of the genetic diversity of Mimosa caesalpiniaefolia Benth. Idesia, 34: 47-52, 2016.

AVELINO, M. C. S. et al. Biochemical tests of membrane integrity on evaluation of vigor of Mimosa caesalpiniifolia Benth. seeds. Revista de Ciências Agrárias, 41: 100-108, 2018.

BELARMINO, K. S. et al. Genetic diversity in a Poincianella pyramidalis (Tul.) L.P. Queiroz population assessed by RAPD molecular markers. Genetics and Molecular Research, 16: 1-10, 2017.

BLOCHTEIN, B. et al. Aspectos da biologia floral, visitantes florais e sucesso reprodutivo de Mimosa caesalpiniifolia (Beth) em Limoeiro do Norte, Ceará, Brasil. In: VIANA, B. F.; SILVA, F. O. (Eds.). Biologia e ecologia da polinização. Salvador, BA: EDUFBA, 2010, v. 2, cap. 2, p. 137-146.

BOTSTEIN, D. et al. Construction of a genetic linkage map in man using restriction fragment length polymorphisms. The American Journal of Human Genetics, 32: 314-331, 1980.

BRASIL. Ministério da Agricultura, Pecuária e Abastecimento. Regras para análise de sementes. Ministério da Agricultura, Pecuária e Abastecimento. Secretaria de Defesa Agropecuária. Brasília: MAPA/ ACS, 2009. 399 p.

BRASIL. Ministério da Agricultura, Pecuária e Abastecimento. Instruções para a análise de sementes de espécies florestais. Ministério da Agricultura, Pecuária e Abastecimento. Secretaria de Defesa Agropecuária. Brasília: MAPA/ACS, 2013. $98 \mathrm{p}$. 
CORREIA, L. A. S. et al. Morphometric descriptors and physiological seed quality for selecting Aspidosperma pyrifolium Mart. matrix trees. Revista Caatinga, 32: 751-759, 2019.

COSTA, M. F. et al. Characterization and genetic divergence of Casearia grandiflora populations in the Cerrado of Piaui State, Brazil. Floresta e Ambiente, 23: 387- 396, 2016.

COSTA, M. G. et al. Leguminous trees to recovery of degraded pastures in northern Rio de Janeiro, Brazil. Scientia Forestalis, 42: 101-112, 2014.

DOYLE, J. J.; DOYLE, J. L. Isolatin of plant DNA from fresh tissue. Focus, 12: 13-15, 1990.

DUARTE, M. M.; NOGUEIRA, A. C.; VIEIRA, E. S. N. Diversity and spatial genetic structure of natural populations of Ziziphus joazeiro Mart. Revista Brasileira de Ciências Agrárias, 13: e5573, 2018

FELIX, F. C. et al. Biometry of Pityrocarpa moniliformis seeds using digital imaging: implications for studies of genetic divergence. Revista Brasileira de Ciências Agrárias, 15: e6128, 2020.

GONZALES, J. L. S.; VALERI, S. V.; PAULA, R. C. Seed physiological quality of different Corymbia citriodora (Hook.) K. D. Hill \& L.A.S. Johnson mother trees. Scientia Forestalis, 39: 171-181, 2011.

KRZYZANOWSKI, F. C.; FRANÇA NETO, J. B. Vigor de sementes. Informativo ABRATES, 11: 81 $-84,2001$.

LIMA, C. R. et al. Physiological quality of seeds from different parent trees of Poincianella pyramidalis (Tul.) L. P. Queiroz. Revista Ciência Agronômica, 45: 370-378, 2014.

MAGUIRE, J. D. Speed of germination: aid in selection and evaluation for seedling emergence and vigour. Crop Science, 2: 176-177, 1962.

MANFIO, C. E. et al. Evaluation of macaw palm progenies in juvenile phase and estimates of genetic parameters and genetic diversity. Pesquisa Florestal Brasileira, 32: 63-68, 2012.

MARCOS FILHO, J. Fisiologia de sementes de plantas cultivadas. 2. ed. Londrina, PR: ABRATES, 2015. 659 p.

NOGUEIRA, A. C.; MEDEIROS, A. C. S. Coleta de sementes florestais nativas. Colombo, PR: Embrapa
Florestas, 2007. 11 p.

PANOBIANCO, M.; VIEIRA, R. D.; PERECIN, D. Electrical conductivity as an indicator of pea seed aging of stored at different temperatures. Scientia Agricola, 64: 119-124, 2007.

RABBANI, A. R. C.; SILVA-MANN, R.; FERREIRA, R. A. Genetic variability of Genipa americana $\mathrm{L}$. belonging to the lower course of São Francisco river. Revista Árvore, 36: 401-409, 2012.

ROVERI NETO, A.; PAULA, R. C. Variability among mother trees of Ceiba speciosa St. Hil for characteristics of the fruits and seeds. Revista Ciência Agronômica, 48: 318-327, 2017.

NUNES, R. T. C. et al. Vigor de sementes de Amburana cearensis (All.) A.C. Smith provenientes de diferentes plantas matrizes. Acta Iguazu, 8: 12$22,2019$.

SEBBENN, A. M. Número de árvores matrizes e conceitos genéticos na coleta de sementes para reflorestamentos com espécies nativas. Revista do Instituto Florestal, 14: 115-132, 2002.

SHABAN, M. Review on physiological aspects of seed deterioration. International Journal of Agriculture and Crop Sciences, 6: 627-631, 2013.

SILVA, K. B. et al. Germination and character variability of fruits and seeds between mother trees of Sideroxylon obtusifolium (Roem. \& Schult.) T.D. Penn. Revista Eletrônica de Biologia, 7: 281-300, 2014a.

SILVA, V. N. et al. Electrical conductivity test with parts of bean seeds. Revista de Ciências Agrárias, 37: 206-213, 2014b.

SILVA JÚNIOR, A. L. et al. Genetic diversity of Schizolobium parahyba var. amazonicum (Huber ex. Ducke) Barneby, in a forest area in Brazil. Genetics and Molecular Research, 16: 1-10, 2017.

YIING, T. S. et al. Genetic diversity of Neolamarckia cadamba using dominant DNA markers based on Inter-Simple Sequence Repeats (ISSRs) in Sarawak. Advances in Applied Science Research, 5: 458-463, 2014 